Article

\title{
Familism and Social Inclusion: Hispanics in New London, Connecticut
}

María Amparo Cruz-Saco ${ }^{1,2}$ and Mónika López-Anuarbe ${ }^{1}$

${ }^{1}$ Economics Department, Connecticut College, 270 Mohegan Avenue, New London, CT 06320, USA;

E-Mail: macru@conncoll.edu (M.A.C.-S.); manuarbe@conncoll.edu (M.L.-A.); Tel.: +1 8604395212 (M.A.C.-S.);

Fax: +18604395332 (M.A.C.-S.)

${ }^{2}$ Research Center (CIUP), Universidad del Pacífico, Jr. Sánchez Cerro 2141, Lima 11, Peru

\section{How to Cite this Article}

Cruz-Saco, M. A., \& López-Anuarbe, M. (2013). Familism and Social Inclusion: Hispanics in New London, Connecticut. Social Inclusion, 1(2), 113-125.

\section{Acknowledgement}

This Article was published by Librello, Social Inclusion's former publisher.

\section{About the Journal}

Social Inclusion is a peer-reviewed open access journal which provides academics and policy-makers with a forum to discuss and promote a more socially inclusive society. The journal encourages researchers to publish their results on topics concerning social and cultural cohesiveness, marginalized social groups, social stratification, minority-majority interaction, cultural diversity, national identity, and core-periphery relations, while making significant contributions to the understanding and enhancement of social inclusion worldwide.

www.cogitatiopress.com/socialinclusion

\section{Editor-in-Chief}

Professor Ulf R. Hedetoft, Faculty of Humanities, University of Copenhagen, Denmark

\section{Managing Editor}

Mr. António Vieira, Social Inclusion, Cogitatio Press, Portugal 


\title{
Familism and Social Inclusion: Hispanics in New London, Connecticut
}

\author{
María Amparo Cruz-Saco ${ }^{1,2, *}$ and Mónika López-Anuarbe ${ }^{1}$ \\ ${ }^{1}$ Economics Department, Connecticut College, 270 Mohegan Avenue, New London, CT 06320, USA; \\ E-Mail: macru@conncoll.edu (M.A.C.-S.); manuarbe@conncoll.edu (M.L.-A.); Tel.: +18604395212 (M.A.C.-S.); \\ Fax: +18604395332 (M.A.C.-S.) \\ ${ }^{2}$ Research Center (CIUP), Universidad del Pacífico, Jr. Sánchez Cerro 2141, Lima 11, Peru \\ * Corresponding author
}

Submitted: 17 September 2013 | In revised form: 18 October 2013 | Accepted: 4 November 2013 |

Published: 21 November 2013

\begin{abstract}
This paper analyzes the financial support and inclusiveness within Hispanic families in New London, Connecticut, and the causes of their social exclusion in the larger society. We designed and administered a survey of 114 items that was answered by 148 participants representing $1.3 \%$ of the non-Puerto Rican Hispanic population. Using factor analysis, we reduced a large number of items in two familism scores to four latent factors: "Financial Support for Family", "Obligation to Family", "Plan to Return", and "Filial Responsibility". We found that financial support for family and obligation to family are strongly endorsed by participants. Approximately one-half would return back to their home countries where they believe to be happier. One-fifth rejects this option. Three-quarters of participants remit money to family, parents in particular, who reside in countries of origin. In contrast to other studies, remitting money is not affected by any given personal characteristic such as gender, income or level of education. Similarly, participants remit irrespective of their degree of self-reported familism measured by scores on the latent factors. A large incidence of poverty among this population, lack of English proficiency, low skills, immigration status, and a lack of voice and political representation inhibit their social inclusion.
\end{abstract}

Keywords: familism; hispanics; migration; remittances; social inclusion

\section{Introduction}

More than two decades ago, the World Summit for Social Development (WSSD) [1] established that inclusion and social integration should be the goals of social development. Since the WSSD, the goal of creating socially inclusive programs seeks to improve how people and communities take part in society, augmenting their opportunity beyond any identity disadvantage such as age, culture, disability, ethnicity, gender, nationality, political and religious beliefs [2]. Through unity across diversity, people should actively participate in society and attain the freedom and development proposed by Amartya Sen [3]. While achieving an inclusive society 
appears as a normative, highly desirable imperative, often too cultural, socio-economic and political structures prevent its attainment.

In the case of a large number of Hispanic migrants in the United States (U.S.), who left their homes mostly for economic reasons and political motivations, the relative larger incidence of low-paying jobs, ineffective schools, inadequate housing, poverty and discrimination negatively affects their inclusion. This situation is more severe in U.S. communities that have recently received an influx of Hispanic migrants where they confront several challenges including a language barrier, employability issues, and lack of a voice and political representation despite their increasing numbers.

As has been documented, Hispanics [4] have high levels of familism, defined as bonding among relatives and kin [5], intergenerational solidarity and relative sacrifice of self for the good of parents and children [6-9]. In other words, the Hispanic culture reflects a high degree of inclusion within the nuclear, extended family, and the community of residence (the "barrio"). A dichotomy in the experience of Hispanics is apparent: they live inclusively in their communities of relatives and kin, but are caught between a rock and a hard place in the larger society.

In this paper, we analyze the case of Hispanics residing in the small town of New London, Connecticut. This is a town of approximately 30,000 residents of which one third is Hispanic, up from $12 \%$ in 1990 . We selected New London because its demographic and socio-economic profile illustrates a repeated pattern in the U.S. The recent affluence of Hispanic migrants is leading to greater diversity in the demographic composition of towns and adjustments in services provided to residents. Changes are visible in the growth of groceries and food services catered to Hispanics, the hiring of bilingual health professionals and teachers, the creation of magnet schools with bilingual programs, and the expansion of diverse religious support services in Spanish. These changes, however, do not imply a gain in political cloud or influence in decisionmaking.

Our research goals were two-fold. First, we aimed to represent familism among the Hispanic non-Puerto Rican community of New London, and to obtain latent factors that define bonding and sense of family commitment. Puerto Ricans were excluded because, as U.S. citizens, they have a fluid relationship with the island of Puerto Rico, so they do not define themselves as migrants in the same way that other Latin American and Caribbean nationals do; they are also covered by Social Security and other welfare programs from which non-U.S. born Hispanics who are not naturalized U.S. citizens are excluded. We used these factors to assess how they relate to remittance behavior and show the transnational sense of obligation and inclusiveness of migrants with family left behind. Second, we were interested in identifying obstacles and perceived challenges that may lead to feelings of social exclusion. To attain said goals, we designed and conducted a comprehensive survey that was administered to 148 participants.

Our main findings confirm the strong familism that characterizes Hispanics and their financial commitment to relatives in the U.S. and in their home countries. More than half of our respondents felt that they would be happier in their national homes, and 75\% remitted money. A large proportion of respondents felt a sense of cultural isolation and exclusion due to obstacles such as language barriers; skills, training and opportunities to access good paying jobs; and, lack of political representation.

\section{Familism and Remittances}

An important proportion of the more than 50 million Hispanics residing in the U.S. [10] transfer more than $\$ 55$ billion annually to Latin America and the Caribbean. With approximately 11 million Hispanics of Mexican descents living in the U.S., more than half this flow is sent to Mexico alone. Although the number of new Hispanic migrants decreased recently, remittances are expected to continue growing due in part to the strengthening of international financial intermediation [11] and the "stock effect" of migrants residing in the U.S. [12-17].

Globally, motives for remitting in diverse migration corridors include altruism, reciprocity or exchange, insurance, loan repayment, and investment in home countries [18-23]. Personal attributes such as gender, socio-economic background, and level of education affect the likelihood and value of money transfers [2429], as well as remittances in kind through gifts or voluntary work and technical advice. Studies have estimated whether there is a gender gap in the probability of remitting, or if years of education and income affect remittance behavior. In this paper, we argue that familism, understood as loyalty, solidarity, bonding, and identification with nuclear and extended family and subordination of self, is also a motive for remitting. Accordingly, it is possible to interpret familism as a social structure that helps promote the bonding and intergenerational ties in families and kin through the financial support that members provide. Such structure reflects the emphasis on the importance of the family and kin over the individual.

Some analysts have modeled familism as intergenerational solidarity and use multivariate methods to measure family affection, association, norms, exchange and consensus [30,31], family ambiguity, and conflict $[32,33]$. Others have used factor analysis to measure the attitudinal and behavioral patterns among Hispanics [34], whites and non-whites to assess degree of familism and how it can be affected by assimilation [35]. Measuring degree of familism among Hispanics, however, has difficulties due to changes in cultural values and attitudes over time and according to the national origin of Hispanics. Indeed, being "Hispanic" is an eth- 
nicity category politically constructed in the U.S. and there are notorious identity differences among subgroups of citizens from different national origins (Chicanos, Cuban, Puerto Ricans, Dominicans, Mexicans, Central and South Americans) and based on diverse social, historical and familial background $[8,36]$. In addition, the Hispanic sense of self and family is also affected by the spatial distribution in the U.S. [37-39].

Surveys in small Hispanic communities have shown that a large percentage remits money [25,40-42]. When migrant groups mature, they continue to remit both at the individual level to family members, and collectively, through organized diasporas which fund small community projects such as investments in infrastructure and the provision of social services for children or the elderly $[17,43]$. The amount remitted may vary from "minuscule" [44] to an average of a few hundred dollars a month $[17,45-51]$.

\section{Research Questions and Method}

The dichotomy between cultural traditions of inclusiveness and solidarity among Hispanics and the harsh realities of poverty and marginalization in the larger context of living in the U.S. becomes apparent when a particular Hispanic community is analyzed. We were interested in the questions: what are the critical factors that define familism and inclusiveness within the New London Hispanic community? How do they relate to giving and remittances? In what ways are Hispanics running the risk of non-inclusion in the larger white community?

Our research approach entailed three steps. First, we designed a survey and administered it to a representative sample of Hispanics residing in New London. Then, we used factor analysis to extract unobserved factors representing familism, happiness, and plan to return back to one's country of origin. Factor analysis was used in two separate familism scales to obtain four factors. And third, we summarized feedback from participants who described their perceptions on why they felt excluded.

The following sections present the survey description, factor analysis findings, participants' feedback on social inclusion, and the conclusions.

\section{Survey Description}

\subsection{The Site of New London, CT}

New London is one of more than twenty cities and towns of New London County [52]. With a long history and a diverse population of 27,707 individuals [53], it is one of the smallest cities in the state [54]. Of the total Hispanic population, approximately $60 \%$ is of Puerto Rican origin [55] and this proportion has been decreasing due to the rising presence of migrants from Latin America.

The affluence of Hispanics will continue to increase as more and more persons reunify with their relatives and others relocate from larger urban centers in New Jersey or New York as well as from Puerto Rico, Colombia, the Dominican Republic, Ecuador, El Salvador, Mexico, and Peru. $16.6 \%$ of the population is foreign born (an increase of $2 \%$ points in two years), which accounts for almost all non-Puerto Rican Hispanics, and $31.5 \%$ (up from $26 \%$ in 2010 ) spoke a language other than English at home [53]. The estimated per capita income in 2011 (for 2007-2011) was $\$ 22,386,60 \%$ the value for the state of Connecticut [53]. High inequality is also apparent when contrasting the per capita income with the median income of $\$ 45$, 509 in New London, much lower that the state median income of $\$ 69,243$ [53]. The incidence of poverty in New London is $18 \%$, but only $10 \%$ in Connecticut. In the Norwich-New London urbanized area, the incidence of poverty among Hispanics of any race is $21.6 \%$, and whites alone, $8.1 \%$ [56].

\subsection{Survey Design, Data Collection, and Survey Participants}

We designed a survey with four sections and 114 response entries, both in Spanish and English (available upon request). In the first section, we included categorical questions such as demographics, length of residence in the U.S., education, socio- economic status, migrant networks, co-residence with partner and children, whether participant sends money home, how they transfer money, to whom, for what, and the cost of sending money. In the second section, we adopted the Lugo-Steidel \& Contreras (LSC) Attitudinal Familism Scale (AFS) [34]. Their measure had 18 items, and responses were based on a 10-point Likert-type scale, ranging from 1 (strongly disagree) to 10 (strongly agree). In the third section, we designed and used a 15-item scale on Family Responsibility and Happiness using a seven-point Likert-type scale (asking "to what degree" questions) ranging from 1 (not at all) to 7 (very much). The fourth and last section consisted of an open ended question that prompted participants to share their views on how included they felt in New London and why.

In the various sites, we approached participants in person, introduced ourselves, explained the goals of the study, appealed to the need for information, promised to share results with Hispanic organizations, and guaranteed anonymity. Participants had the choice of completing the survey in English or Spanish. All chose to answer the survey in Spanish. They signed a consent form before completing the survey and were given an information sheet with the name of the principal investigator and their contact information. Each survey took approximately 45 minutes to complete, including time to share any feedback on their experience of inclusion in New London. The research team met periodically to debrief on fieldwork, discuss emerging themes from open-ended question, and ensure correspondence of the sample with the major characteristics 
of the Hispanic non-Puerto Rican population in New London.

Data for the analysis came from 148 survey responses from non-Puerto Rican Hispanic residents in New London representing $1.3 \%$ of this population $(148 / 27,707 \times 0.4=0.0133)$. Participants were ages 18 and older, had resided in the U.S. for at least two years, and were Hispanic of non-Puerto Rican origin. Participants were originally identified through Hispanic organizations, including the Hispanic Alliance of Southeastern Connecticut, the New London Community Health Center, the Provenance Center, and local businesses that employ and serve the Hispanic community (supermarkets, Latino restaurants, beauty shops, travel agencies and tax management offices).

\subsection{Description of Participants}

The gender of participants in our sample was fairly balanced (females, 53\%), the median age was 41 and the median time of residence in the U.S. was 11 years [57]. Eighty-two percent of our subjects were born in six Latin American countries: Colombia, the Dominican Republic, Ecuador, El Salvador, Honduras, and Peru, and only $7.4 \%$ were born in Mexico. This contrasts with the majority presence of Mexicans at the national level. Approximately one-third of participants reported being a U.S. citizen, a permanent resident, or with their immigration status "in progress". The latter category comprised a person who was "not currently a citizen" and was filing for a green card to become "documented"; a person filing for citizenship, waiting for a change in immigration legislation and not currently with lawful alien status, or any other reason. Of the third category, "not currently a citizen", most wished to acquire U.S. citizenship. Persons in this category, one-third of our participants, were in the most vulnerable position.

Two-thirds wanted to belong to a Hispanic cultural or social group, and over $82 \%$ spoke Spanish at home. Less than one-third reported speaking excellent English. Forty-three percent had attained a high school or GED diploma, $48 \%$ had some trading or bachelor's equivalent degree, and only $7 \%$ had completed graduate studies. Major obstacles for job advancement included English proficiency, degree training, and on-the-job skills. Despite relatively long years of residence in the U.S., many participants had not acquired proficiency in English due to their need to be engaged in income generating activities with little time to learn English.

One-third of our sample had a full-time job with benefits, while the remainder had combinations of full-time jobs without benefits, part-time jobs, and some form of self-employment. This situation signals vulnerability of Hispanics for the acquisition of benefits such as health care and retirement savings. 19\% indicated that they did not work because they were out of the labor force (moms of small children, unemployed or retired). The mean monthly income for the sample was $\$ 1,782$; one-third made less than $\$ 999,39 \%$ between $\$ 1,000$ and $\$ 1,999$, and the rest more than $\$ 2,000$ (participants with graduate studies). Almost two-thirds of participants needed financial help sometimes $(54.1 \%)$ or always $(10.8 \%)$. The median number of people in their household was three; more than half resided with a partner and with up to two children, and $63 \%$ had children in the U.S. More than two-thirds of participants rented, sublet, or lived with a relative or a friend, and $25 \%$ reported owning their residence.

These figures show that the mean income of participants $(\$ 1,782 \times 12=\$ 21,384)$ is slightly less than the per capita income for New London at $\$ 22,386$ [53]. One-third of the participants, with an average of three persons in the household, earned incomes that were approximately $60 \%$ the poverty threshold of $\$ 18,500$ in the U.S. [58]. More than one-half of participants were on or below this poverty threshold. This finding is consistent with the realization that almost two-thirds of the respondents needed financial help at least sometimes and shows that our sample is financially vulnerable. Since one-third of them are neither legal resident aliens nor U.S. citizens, it is possible to infer that welfare programs do not cover them. Their livelihood depends largely on any income generating activity that they can find supplemented by social service programs from organizations such as soup kitchens, not-for profit health care organizations, and charity programs that operate in town.

Despite their vulnerability, three-quarters of respondents remitted money back home on a frequent (at least once a month) or regular (at least once a year) basis, and $40 \%$ had sent money in the past. They made electronic transfers to their nuclear family (spouse and children, 21\%), their parents (50\%), their extended families (27\%), and their communities $(8 \%)$. Close to three-quarters of participants considered that the cost of remitting was high, although substantial reductions in transaction costs have taken place in recent years.

On average, the sample reflected a population that is low income, low skill, with a critical number of participants with their immigration status "in progress", needing to improve their English, renting a home, having been in the U.S. for a decade, and remitting money to their nuclear family and parents. Our analysis of variance of "sending money" by personal characteristics (gender, age, education, income, length of stay in the U.S., number of children, etc.) showed that we cannot reject the null hypothesis that all treatments have the same effect, i.e., participants remit regardless of any personal attribute.

\section{Factor Analysis Results}

\subsection{The LSC AFS Scale (18 Items)}

We applied the Lugo Steidel \& Contreras' AFS [34] comprising 18 items to the principal component ana- 
lysis (PCA) using SPSS version 19. The correlation matrix revealed that three items $(3,9$ and 16$)$ had coefficients less than 0.3 , thus we eliminated them from the analysis.

Thus, our data matrix contained 15 items and 132 subjects. The value of the Kaiser-Meyer-Olkin (KMO) was 0.89 , above the recommended value of 0.6 , and Bartlett's Test of Sphericity was highly significant. Thus, we could safely proceed to use factor analysis to distill components. Two factors or components were extracted with eigenvalues 7.15 and 1.72 , respectively, explaining $47.7 \%$ and $11.5 \%$, for a total cumulative variance of $59.1 \%$. The Scree plot showed that there is a clear break after the second component. We also performed oblimin rotation to aid in the interpretation of these two components. This rotation showed that three items loaded relatively high on both components, thus revealing that our results did not generate a "clean" output.

Item 11, "a person should live near his or her parents and spend time with them on a regular basis" loads 0.530 on the first component and 0.402 on the second (see columns 1 and 2 in Table 1). This was also true for item 12, "a person should always support members of the extended family, for example, aunts, uncles, and in-laws, if they are in need even if it is a bid sacrifice". It loads 0.510 on the first component and 0.388 on the second. Because of their relatively higher loads on the first component, these items were included in it. Item 15, "children should obey their parents without question even if they believe they are wrong" loads 0.344 on the first component and 0.585 on the second. Again, since the loading was higher on the second component, this item was placed in it.

Next, we interpreted the item composition in each factor to produce a name for the latent component. The first component contains twelve items and explains $47.7 \%$ of the total variance as can be seen in Table 1 . These twelve items are pulled together through factor analysis and reflect family expectations of a person regarding help to siblings, parents, other relatives; relying on each other for family support; defending the honor of the family; respecting older members such as, older siblings and older parents; living nearby and being good to each other. This sense of commitment or duty to the family that suggests subjugation of self can be adequately summarized in a factor named "Obligation to Family". The second component, that adds $11.5 \%$ to the variance, contains three items on how children should behave regarding their parents. Basically, these items indicate that children should live with their parents, obey them, and share their income with them. A suitable name for this factor is "Filial Responsibility".

Thus, the two latent factors that were obtained from replicating the LSC (2003) score were "Obligation to Family" and "Filial Responsibility". These results depart from their four components: "Familial Support", "Familial Interconnectedness", "Familial Honor", and "Subjuga- tion of Self for Family". One possible explanation is that in our sample the subtle differences among dimensions such as support, interconnectedness, honor, and subjugation of self were not as clear and were subsumed in the more inclusive component of "Obligation to Family". Also, we excluded three items from their original 18-item list. Finally, while the size of LSC sample in Cleveland (124) and the New London sample (132) are comparable, the level of assimilation of our participants may explain the difference in results. LSC (2003) recruited relatively less acculturated Latinos, whereas our participants had a median residence of 11 years in the U.S.

\subsection{The Familism and Happiness Scale (15 Items)}

Table 2 presents participants' answers to the familism and happiness scale. The answers are ranked according to the item with the highest percent of agreement.

More than three-quarters of respondents strongly agree with statements that refer to their desire to be in more physical proximity with relatives left behind in countries of origin, with feelings that remittances are used in the manner they attempted, wanting to help fund their aging parents, and wanting to remit more. Approximately seventy percent of respondents strongly agree that parents should make sacrifices to support their children without expecting retribution, though they may not be doing enough given their particular situations. Close to sixty percent of respondents strongly agree that they would be happier in their home countries, they would invest there, and believe that their experience in the U.S. is changing their attitudes toward gender and family roles. When asked directly, half of respondents would go back home to live permanently.

These answers show a strong connection of respondents with their extended family in countries of origin. On average, respondents have been residing in the U.S. for more than ten years and acknowledge that their attitudes toward gender and family roles are changing, however, they long for close proximity with their loved ones at home and send money because they feel obligated to support their family. One in two would return and $60 \%$ believe that they would be happier at home, in their countries of origin.

We then subjected our 15-item scale on family responsibility and happiness to PCA. We omitted four variables from the 15 item questionnaire of the factor analysis because their correlation matrix coefficients were very low. The correlation matrix showed low coefficients but strong enough to proceed with the analysis, as this scale contained items that included plans to return to home countries and whether participants would be happier returning. The KMO at 0.65 was above the recommended value of 0.6, and the Bartlett's Test of Sphericity showed statistical significance. Results are presented in Table 3. 
Table 1. Pattern and structure matrix for the LSC AFS Familism Scale.

\begin{tabular}{|c|c|c|c|c|}
\hline \multirow{2}{*}{ Item/ Factor Loading (*) } & \multicolumn{2}{|c|}{ Pattern Coefficient } & \multicolumn{2}{|c|}{ Structure Coefficient } \\
\hline & $\begin{array}{l}\text { "Obligation } \\
\text { to Family" }\end{array}$ & $\begin{array}{c}\text { "Filial } \\
\text { Responsibility" }\end{array}$ & $\begin{array}{l}\text { "Obligation } \\
\text { to Family" }\end{array}$ & $\begin{array}{c}\text { "Filial } \\
\text { Responsibility" }\end{array}$ \\
\hline
\end{tabular}

Factor: "Obligation to Family"

1. Children should help out around the house

0.914

0.910

2. A person should often do activities with his or her immediate and extended families, for example, eat meals, play games, or go somewhere together.

3. The family should control the behavior of children younger than 18 .

4. A person should rely on his or her family if the need arises.

5. Children should always help their parents with the support of younger brothers and sisters, for example, help them with homework, help the parents take care of the children, and so forth.

6. A person should always be expected to defend his/her family's honor no matter what the cost.

7. A person should respect his or her older brothers and sisters regardless of their differences in views.

8. Aging parents should live with their relatives.

9. A person should feel ashamed if something he or she does dishonors the family name.

10. A person should be a good person for the sake of his or her family.

11. A person should live near his or her parents and spend time with them on a regular basis.

12. A person should always support members of the extended family, for example, aunts, uncles, and in-laws, if they are in need even if it is a bid sacrifice. $\begin{array}{lll}\mathbf{0 . 5 9 7} & 0.631 & 0.296\end{array}$

$\begin{array}{lll}0.545 & 0.627 & 0.434\end{array}$

$\begin{array}{llll}\mathbf{0 . 5 3 0} & 0.402 & 0.654 & 0.566\end{array}$

$\begin{array}{llll}\mathbf{0 . 5 1 0} & 0.388 & 0.630 & 0.545\end{array}$

\section{Factor: "Filial Responsibility"}

13. Children should live with their parents until

$\begin{array}{lll}\mathbf{0 . 7 8 8} & 0.153 & 0.761\end{array}$
they get married.

14. Children younger than 18 should give

$\begin{array}{lll}\mathbf{0 . 7 6 1} & 0.195 & 0.748\end{array}$
almost all their earnings to their parents.

15. Children should obey their parents without question even if they believe they are wrong.

Percentage of explained Variance

$47.7 \quad 11.5$

Cumulative percentage of explained variance

47.7

59.2

Source: [59]. The numbering of items according to the survey. $\left(^{*}\right) \mathrm{N}=132$. Only factor loadings of 0.30 or higher are presented in the pattern and structure matrix. 
Table 2. 15 item scale on family responsibility and happiness.

\begin{tabular}{|c|c|c|}
\hline Item/Question or Statement & $\mathbf{n}$ & $\begin{array}{c}\text { Strongly } \\
\text { agree, \% }(*)\end{array}$ \\
\hline $\begin{array}{l}\text { 47. To what degree would you like more physical proximity with your family members } \\
\text { who are at home? }\end{array}$ & 118 & 87.4 \\
\hline 45. To what degree do you feel that the monies are used in the way you attempted? & 118 & 84.7 \\
\hline 58.2 Individuals are supposed to financially support their aging parents. & 137 & 80.3 \\
\hline $\begin{array}{l}\text { 48. To what degree do you think that you would like to increase the money sent } \\
\text { home? }\end{array}$ & 117 & 78.7 \\
\hline 58.3 There are situations when parents can't support financially their families. & 135 & 73.4 \\
\hline 58.4 Parents should make personal sacrifices to financially support their children. & 135 & 71.9 \\
\hline 46. To what degree do you feel that you are strongly supporting your kin? & 116 & 71.6 \\
\hline $\begin{array}{l}58.1 \text { Parents are expected to financially support their children without expectation of } \\
\text { retribution. }\end{array}$ & 136 & 69.1 \\
\hline 51. To what degree are you interested in investing money in your home country? & 127 & 59.9 \\
\hline $\begin{array}{l}58.6 \text { My experience in the USA is changing my attitude toward gender and family } \\
\text { roles }\end{array}$ & 136 & 59.6 \\
\hline 58.7 I feel that I would be happier in my home country. & 137 & 59.1 \\
\hline $\begin{array}{l}58.5 \text { If Governments would pay pensions to older persons then I wouldn't send } \\
\text { money to my parents. }\end{array}$ & 133 & 55.6 \\
\hline 49. To what degree would you like to change the way you send money home? & 117 & 51.3 \\
\hline $\begin{array}{l}\text { 52. To what degree are you interested in going back to your home country to live } \\
\text { permanently? }\end{array}$ & 125 & 50.4 \\
\hline $\begin{array}{l}\text { 50. To what degree would you like to use international banking to facilitate sending } \\
\text { money home? }\end{array}$ & 120 & 49.1 \\
\hline
\end{tabular}

Table 3. Pattern and structure matrix for the scale on family responsibility and happiness.

\begin{tabular}{|c|c|c|c|c|c|}
\hline \multirow[t]{2}{*}{ Item/ Factor Loading (*) } & \multicolumn{2}{|c|}{ Pattern Coefficient } & \multicolumn{2}{|c|}{ Structure Coefficient } & \multirow[t]{2}{*}{ Communalities } \\
\hline & $\begin{array}{l}\text { "Plan to } \\
\text { Return" }\end{array}$ & $\begin{array}{l}\text { "Financial } \\
\text { Support for } \\
\text { Family" }\end{array}$ & $\begin{array}{l}\text { "Plan to } \\
\text { Return" }\end{array}$ & $\begin{array}{l}\text { "Financial } \\
\text { Support for } \\
\text { Family" }\end{array}$ & \\
\hline \multicolumn{6}{|l|}{ Factor: "Plan to Return" } \\
\hline $\begin{array}{l}\text { 51. To what degree are you interested in } \\
\text { investing money in your home country? }\end{array}$ & 0.857 & & 0.828 & & 0.706 \\
\hline $\begin{array}{l}58.7 \text { I feel that I would be happier in my } \\
\text { home country. }\end{array}$ & 0.720 & & 0.690 & & 0.481 \\
\hline $\begin{array}{l}\text { 52. To what degree are you interested in } \\
\text { going back to your home country to live } \\
\text { permanently? }\end{array}$ & 0.701 & & 0.693 & & 0.498 \\
\hline $\begin{array}{l}\text { 48. To what degree do you think that you } \\
\text { would like to increase the money sent } \\
\text { home? }\end{array}$ & 0.520 & & 0.564 & 0.320 & 0.362 \\
\hline $\begin{array}{l}\text { 49. To what degree would you like to } \\
\text { change the way you send money home? }\end{array}$ & 0.484 & & 0.501 & & 0.257 \\
\hline $\begin{array}{l}\text { 50. To what degree would you like to use } \\
\text { international banking to facilitate sending } \\
\text { money home? }\end{array}$ & 0.454 & & 0.493 & & 0.280 \\
\hline
\end{tabular}




\section{Factor: "Financial Support for Family"}

58.4 Parents should make personal sacrifices to financially support their children.

58.1 Parents are expected to financially support their children without expectation of retribution.

58.3 There are situations when parents can't support financially their families.

45. To what degree do you feel that the monies are used in the way you attempted?

47. To what degree would you like more physical proximity with your family members who are at home?

Percentage of explained Variance

Cumulative percentage of explained variance

Source: [59], numbering of items according to the survey presented for the pattern and structure matrixes.

We extracted two components that explained $25.4 \%$ and $15.5 \%$ of the total variance, respectively, for a cumulative variance of $40.9 \%$. Both components had eigenvalues equal to 2.8 and 1.7 respectively. Loadings in the pattern matrix cleanly separated into each of the components.

When the oblimin rotation was performed, the structure matrix delivered loadings that were fairly consistent with the pattern matrix, thus validating the aggregation of items into two components.

We labeled the latent factors or components to reflect the items that are included in each. The first component includes six items, explains $25.4 \%$ of the variance, and show: desire to invest back at home, where the respondent believes $\mathrm{s} / \mathrm{he}$ would be happier, where $\mathrm{s} / \mathrm{he}$ would want to live permanently, and where s/he wishes to send more money in a more cost-effective manner. We labeled this component "Plan to Return". The second component represents five items and explains another $15.5 \%$ of the variance. Items reflect the commitment of parents to financially support their children without expectation of reciprocity and even incurring in personal sacrifices despite situations when they can't realize their commitment. It also includes the wish to be in physical proximity to relatives at home and the notion that monies they sent are spent according to their anticipated use. This component was labeled "Financial Support for Family".

\subsection{Summary Results}

Based on the factor analysis for the familism scales in Sections 2 and 3 of the survey, we extracted four latent factors or components by degree of agreement presented in Table 4.

The most important factor is financial support of
0.527

(*) $\mathrm{N}=127$. Only factor loading of 0.30 or higher are

family members with only 1.3 percent strongly disagreeing. Second, is obligation to family through chores, care-giving responsibilities, and respect for family and elders. Third, is plan to return back to home country with one-third that is undecided and approximately one-fifth that strongly disagrees with this option. And finally, the factor of filial responsibility was less forcefully supported. The items in this factor are presented at the bottom of Table 1, and they imply strong subordination of children to parents. Yet, a relatively low proportion of disagreement, $9.4 \%$, exists with such blunt statements.

Since we are interested in the relationship between these factors and remitting behavior, we completed cross-tabulations of the latter with sending money back home presented in Table 5. As can be observed, most participants sent money back home even in the few cases when they strongly disagreed with the factor. Basically, participants felt that financial support for their family was critically important.

A clearer picture of how a participant's personal characteristics relate to sending money can be shown in cross-tabulations. For example, of the 76 female participants, $73.3 \%$ remit, and of the 83 male participants, $82.1 \%$ remit-and there is no statistical difference in these proportions. With regard to age, of the 79 participants who are younger than 45, 77.2\% remit, and of 55 participants older than 45, 74.5\% remit. The same is true for: years in the U.S., immigration status, need to belong to a cultural or social Hispanic club, language, education, income, etc. None was significant, and we concluded that Hispanic migrants in our sample remit regardless of gender, age, years residing in the U.S., level of education, size of family in countries of origin, income level, and other characteristics. 
Table 4. Factors and self-reported agreement or disagreement by participants, in \%.

\begin{tabular}{lcccc}
\hline Latent Factor & $\begin{array}{c}\text { Strongly } \\
\text { agree }\end{array}$ & $\begin{array}{c}\text { Neither agree } \\
\text { nor disagree }\end{array}$ & $\begin{array}{c}\text { Strongly } \\
\text { disagree }\end{array}$ & Total \\
\hline "Financial Support for Family" & 72.4 & 26.3 & 1.3 & 100.0 \\
"Obligation to Family" & 63.6 & 29.5 & 7.0 & 100.0 \\
"Plan to Return" & 45.8 & 35.9 & 18.3 & 100.0 \\
"Filial Responsibility" & 28.1 & 62.5 & 9.4 & 100.0 \\
\hline
\end{tabular}

Source: authors' calculations. For the first two factors based on a 10 point Likert-type scale ranging from 1 (not at all) to 10 (very much), strongly agree are scores of 7 to 10; neither agree nor disagree are scores of 5 to 6 ; strongly disagree are scores of 1 to 4 . For the next two factors based on a 7 point Likert-type scale ranging from 1 to 7, strongly agree are scores 5 to 7; neither agree nor disagree are scores 3 to 4; strongly disagree are scores 1 to 2 .

Table 5. Cross tabulations of factors with sending money.

\begin{tabular}{llccc}
\hline & \multicolumn{3}{c}{ Send money? } \\
& & n & Yes (\%) & No (\%) \\
\hline Plan to Return & Strongly disagree & 22 & 81.8 & 18.2 \\
& Neither agree nor disagree & 43 & 83.7 & 16.3 \\
& Strongly agree & 55 & 81.8 & 18.2 \\
Financial Support for Family & & & \\
& Strongly disagree & 2 & 100 & 0 \\
& Neither agree nor disagree & 31 & 74.2 & 25.8 \\
& Strongly agree & 85 & 85.9 & 14.1 \\
Obligation to Family & & & & \\
& & 9 & 88.9 & 11.1 \\
& Strongly disagree & 38 & 73.7 & 26.3 \\
& Neither agree nor disagree & 82 & 80.5 & 19.5 \\
Filial Responsibility & Strongly agree & & & \\
& & 12 & 75 & 25 \\
& Strongly disagree & 80 & 80 & 20 \\
& Neither agree nor disagree & 36 & 77.8 & 22.2 \\
\hline
\end{tabular}

Source: authors' calculations. For the first two factors based on a 10 point Likert-type scale ranging from 1 (not at all) to 10 (very much), strongly agree are scores of 7 to 10; neither agree nor disagree are scores of 5 to 6 ; strongly disagree are scores of 1 to 4 . For the next two factors based on a 7 point Likert-type scale ranging from 1 to 7 , strongly agree are scores 5 to 7 ; neither agree nor disagree are scores 3 to 4; strongly disagree are scores 1 to 2 .

\section{Participants' Report on Social Exclusion}

Participants felt that family members should help and support each other and believed that geographic proximity was important. While intergenerational reciprocity was acknowledged, a large proportion of middle-age participants stated that children should not feel obliged to help parents financially in old age. Younger people, however, felt strongly about the need to provide care to aging parents or relatives. In general, the idea of co-residence and sharing resources to help each other was accepted. Most felt that they needed to send money home to support an aging parent, a grandparent, a sibling or a member of the nuclear family. One participant reported that she sent as little as \$20 as often as possible.

Three themes stood out. First, participants perceived that the Hispanic population is invisible, often by choice, and fragmented by national origin. A large number of Hispanic migrants preferred to remain "invisible", in part due to the "white" and "non-white" identity clash, and for fear of discrimination. It was reported that, 
despite the seeming tolerance of other racial and ethnic groups in New London, Hispanics were stigmatized mostly due to their accents and family names. Some preferred to remain in their own safe social circles, which may limit their employability and economic autonomy, though this situation is changing with second and third generations. They preferred to reside in neighborhoods with relatives or friends; they supported Latino establishments and, for the most part, spoke Spanish at home. The presence of an undocumented relative or friend either co-residing or living nearby can be a source of anxiety. Our survey showed that one third of our participants had undocumented status which shows the dimension of the immigration issue confronting towns such as New London. In the absence of new immigration laws that begin to solve the legality of the presence of more than eleven million persons in similar condition in the U.S., one should expect that fear and an increasing vulnerability of a population that wishes to remain invisible will only grow.

Second, it was noted that the language barrier affects labor insertion, social inclusion, and the quality of health and education that Hispanic migrants can access. This situation is difficult to overcome because they cannot find time to study English given their need to work full-time, often on different jobs. Many believe that their inability to understand and communicate in English inhibits access to quality health care, which has been documented $[7,60]$ and affects the likelihood of attaining higher-paying jobs, or to purchase much needed health insurance (nationwide, half of Spanish-speaking Hispanics do not have health insurance [61]).

Third, despite being one-third of the New London population, the Hispanic voice is sparsely represented and lacks political and cultural presence. For example, there is only one member of Hispanic heritage on the Board of Education, and no City Council member is Hispanic. Hispanics also lack political participation, and their voting registration rate is low. Nevertheless, our survey revealed that over two-thirds of participants expressed interest in belonging to a cultural Hispanic association, which in itself would be an important first step.

Regarding changes needed to enhance quality of life, it was reported that jobs, on-the-job training and mastering English were necessary conditions to increasing income levels. Most participants agreed that children needed to take advantage of educational opportunities and acquire a college education. One of our participants, who collects trash for a neighboring city, sent his two children to highly selective liberal arts colleges. Another mother of four, who made her living cleaning homes, sent her four children to college, including a son who graduated with a medical degree from an Ivy League school and who is conducting his residency at a prestigious university hospital. Presently, these six second-generation children are professionals with graduate degrees from top U.S. schools.

\section{Conclusion}

Our main finding is that financial support for family and obligation to family best represent the familism observed among non-Puerto Rican Hispanics in New London. This commitment means supporting family both in the U.S. and in countries of origin due to emphasis on the importance of family relative to one's self. Clearly, the obligation to remit may in return elevate the burden and sacrifices that this population is making. Given that for a sizable number of participants, their income levels fall below the poverty threshold in the U.S., the financial support to family members comes with a high dose of sacrifice. Probably for these reasons, approximately one-half of respondents perceived that they would be happier in their home countries. The paradox is that, these challenges notwithstanding, one-fifth would not return.

Living in the U.S., however, has another implicit cost, namely, social exclusion. Inability to speak English, lack of skills and professional training, lack of voice and political representation are factors that inhibit the socio-economic progress of participants. This situation is compounded with lack of access to adequate social services, health care insurance in particular. For one third of our participants with immigration status in progress, their vulnerability is greater.

Our findings confirm the existence of a bifurcated experience where the financial inclusiveness and support of family, relatives and kin is not accompanied by social inclusion in the larger society. Having identified actual and perceived obstacles for greater inclusion, it becomes apparent that policy interventions are needed to promote greater inclusiveness in the town of New London. One general policy intervention is resolution of the immigration status of migrants with undocumented status. Once a process for acquiring legality is in place, these persons will experience a sense of relief and empowerment that will help them integrate more effectively into the larger society for the following reasons. First, acquiring legal status and a reduction in uncertainty will create the right incentive for investing in their human capital. Second, they will be able to put their education in action by finding jobs that pay livable wages. Since income and educational training are positively correlated, higher levels of education will render a drop in their financial vulnerability. At the local level, organizations representing Hispanics in New London should be strengthened through increased local participation of Hispanics and their leaders. Jointly, they should work on selected community goals such as increasing the admit ratio of Hispanic high-school students in colleges and technical schools, attaining universal English proficiency, and securing health care access. The presence of a large number of social service organizations and higher education institutions in the area provide an adequate level of capability and infrastructure that could be effectively mobilized. 


\section{Acknowledgements}

We are particularly grateful for the collaboration of our research assistants Matthew Murdock, Martina Rudolf, and Pedro Paredes without whom this project would not have come to an end. We are also thankful to our

\section{References and Notes}

1. World Summit for Social Development. Available from: http://www.un.org/esa/socdev/wssd/textversion (accessed on 28 July 2013).

2. World Bank. The Foundation for Shared Prosperity. Available from: http://www.worldbank.org/en/topic/ socialdevelopment/brief/inclusion-matters (accessed on 29 August 2013).

3. Sen A. Development as Freedom. Oxford, UK: Oxford University Press; 1999.

4. According to the U.S. Census, Hispanics or Latinos are those people who classified themselves in one of the specific Spanish, Hispanic, or Latino categories listed on the Census 2010 questionnaire -"Mexican", "Puerto Rican", or "Cuban"-as well as those who indicate that they are "another Hispanic, Latino, or Spanish origin" including Spain, the Spanish-speaking countries of Central or South America, or the Dominican Republic. They can be of any race. Although the U.S. Census has begun to use Hispanics or Latinos as if they were synonymous, Hispanics is a more narrow construction than Latinos or Latinas. The former is based on language, i.e., Spanish, and the later on geography, since it is based on the region of Latin America or Latin America and the Caribbean. There is an unavoidable political construction of these labels confuses the identification of persons who speak Spanish at home or who have a Latin American and Caribbean background. This translates into a problem: a large number of persons identified as Hispanics in the U.S. do not necessarily identify this way. In this paper, we acknowledge the difficulties with this identity definition but nonetheless we use the category to refer to persons of Spanish or Hispanic cultural background.

5. The normative imperatives of familism may generate feelings of excessive burden and sacrifice when the financial commitments for family begin to undermine one's own well-being. As such, familism can generate contradictory emotions both positive and negative that are difficult to reconcile.

6. Dennis J, Basañez T, Farahmand A. Intergenerational conflicts among Latinos in early adulthood: Separating values conflicts with parents from acculturation conflicts. Hispanic Journal of Behavioral Sciences. 2009;32(1):118-135.

7. González HM, Vega WA, Tarraf W. The health care quality perceptions among foreign-born Latinos and the importance of speaking the same language. Journal of the American Board of Medicine. 2010;23 (6):745-752. partners the Hispanic Alliance, the Provenance Center, the Community Health Center of New London, and numerous Hispanic residents in New London who opened their businesses and homes and allowed us to conduct this project. Finally, we thank two anonymous reviewers for their very helpful suggestions.

8. Rivera FI, Guarnaccia PJ, Mulvaney-Day N, Lin JY, Torres ME, Alegría M. Family cohesion and its relationship to psychological distress among Latino groups. Hispanic Journal of Behavioral Sciences. 2008;30(3): 357-378.

9. Sabogal F, Marín G, Otero-Sabogal R, Vanoss Marín B, Pérez-Stable EJ. Hispanic familism and acculturation: What changes and what doesn't? Hispanic Journal of Behavioral Sciences. 1987;9(4):397-412.

10. 2010 U.S. Census. Available from: http://2010. census.gov/2010census/data (accessed on 15 January 2013).

11. Yang D. Migrant Remittances. Journal of Economic Perspectives. 2011;25(3):1-24.

12. Acosta P, Calderón C, Fajnzylber P, López H. What is the impact of international remittances on poverty and inequality in Latin America? World Development. 2008;36(1):89-114.

13. García-Fuentes PA, Kennedy PL. Remittances and economic growth in Latin America and the Caribbean: The impact of human capital development. Presented at the Southern Agricultural Economics Association Annual Meeting, Atlanta, GA, USA, 31 January3 February 2009.

14. Maimbo SM, Ratha D, editors. Remittances: Development impact and future prospects. Washington, DC, USA: International Bank for Reconstruction and Development/The World Bank; 2005.

15. United Nations. International migration report 2006: A global assessment. New York, NY, USA: United Nations, Department of Economic and Social Affairs, Population Division; 2009.

16. United Nations Development Program. Human Development Report. Overcoming barriers: Human mobility and development. Available from: http://hdr. undp.org/en/reports/global/hdr2009/chapters (accessed on 20 January 2009).

17. World Bank. Global Economic Prospects. Economic Implications of Remittances and Migration. Washington, DC, USA: World Bank; 2006.

18. Amuedo-Dorantes C, Pozo S. Remittances as Insurance: Evidence from Mexican Immigrants. Journal of Population Economics. 2006;19(2):227-254.

19. Hoddinott J. A model of migration and remittances applied to Western Kenya. Oxford Economic Papers. 1994;46(3):459-476.

20. Osaki K. Economic interactions of migrants and their households of origin: Are women more reliable supporters? Asian and Pacific Migration Journal. 1999; 8(4):447-471.

21. Quinn MA. Remittances, savings, and relative 
rates of return. The Journal of Developing Areas. 2005; 38(2):1-23.

22. Rapoport $H$, Docquier F. The economics of migrant's remittances. In: Kolm SC, Ythier JM, editors. Handbook of the Economics of Giving, Altruism and Reciprocity. New York, NY, USA: Elsevier Science; 2006. pp. 1135-1198.

23. Stark O, Lucas REB. Migration, remittances, and the family. Economic Development and Cultural Change. 1988;36(3):465-481.

24. Bettin G, Lucchetti R, Zazzaro A. Income, consumption and remittances: Evidence from immigrants to Australia. HWWI Research Paper, No. 3-21. Available from: http://ssrn.com/abstract=1498325 (accessed on 10 September 2013).

25. Blue SA. State policy, economics crisis, gender and family ties: Determinants of family remittances to Cuba. Economic Geography. 2004;80(1):63-82.

26. Bollard A, McKenzie $D$, Morten $M$. The remitting patterns of African migrants in the OECD. Journal of African Economies. 2010;19(5):605-634.

27. Holst $E$, Schafer A, Schrooten M. Remittances and gender: Theoretical considerations and empirical evidence. Discussion Paper no. 5472. Bonn, Germany: Institute for the Study of Labor (IZA); 2011.

28. Naufal GS. Why remit? The case of Nicaragua. Discussion Paper no. 3276. Bonn, Germany: Institute for the Study of Labor (IZA); 2008.

29. VanWey L. Altruistic and contractual remittances between male and female migrants and households in rural Thailand. Demography. 2004;41(4):739-756.

30. Bengtson VL, Roberts REL. Intergenerational solidarity in aging families: An example of formal theory construction. Journal of Marriage and the Family. 1991;53(4):856-870.

31. Mangen DJ, Bengtson VL, Landry Jr PH. The measurement of intergenerational relations. Beverly Hills, CA, USA: Sage; 1988.

32. Bengtson VL, Oyama PS. Intergenerational solidarity and conflict: What does it mean and what are the big issues? In: Cruz-Saco MA, Zelenev S, editors. Intergenerational Solidarity: Economic and Social Ties. New York, NY, USA: Palgrave Macmillan; 2010. pp. 35-52.

33. Lowenstein A. Determinants of the complex interchange among generations: Collaboration and conflict. In: Cruz-Saco MA, Zelenev S, editors. Intergenerational Solidarity: Economic and Social Ties. New York, NY, USA: Palgrave Macmillan; 2010. pp. 53-80.

34. Lugo Steidel AG, Contreras JM. A new familism scale for use with Latino populations. Hispanic Journal of Behavioral Sciences. 2003;25(3):312-330.

35. Comeau JA. Race/ethnicity and family contact: Toward a behavioral measure of familialism. Hispanic Journal of Behavioral Sciences. 2012;34(2):251-268.

36. Oboler S. Ethnic labels, Latino lives. Identity and the politics of (re) presentation in the United States. Minneapolis, MN, USA: University of Minnesota Press; 1995.
37. Allen Jr VC, Lachance C, Rios-Ellis B, Kaphingst $\mathrm{KA}$. Issues in the assessment of "race" among Latinos: Implications for research and policy. Hispanic Journal of Behavioral Sciences. 2011;33(4):411-424.

38. Ellis M, Almgren G. Local contexts of immigrant and second-generation integration in the United States. Journal of Ethnic and Migration Studies. 2009; 35(7):1059-1076.

39. Portes A, Fernández-Kelly P, Haller W. The Adaptation of the immigrant second generation in America: A theoretical overview and recent evidence. Journal of Ethnic and Migration Studies. 2009;35(7):1077-1104.

40. Braga Martes AC. The Commitment of return: Remittances of Brazilian émigrés. In: Jouet-Pastré $C$, Braga LJ, editors. Becoming Brazuca: Brazilian Immigration to the United States. Cambridge, MA, USA: Harvard University David Rockefeller Center for Latin American Studies; 2008. pp. 125-150.

41. Suki L. Competition and remittances in Latin America: Lower prices and more efficient markets. Working Paper 2/2007. Washington, DC, USA: InterAmerican Development Bank and Organization for Economic Co-operation and Development; 2007.

42. Levitt P. Roots and routes: Understanding the lives of the second generation transnationally. Journal of Ethnic and Migration Studies. 2009;35(7):12251242.

43. Portes A, Escobar C, Walton Radford A. Immigrant transnational organizations and development: $\mathrm{A}$ comparative study. International Migration Review. 2007; 41(1):242-281.

44. Suro R, Benavides DC, Bendixen S, Lowell BL. Billions in motion: Latino immigrants, remittances and banking. Washington, DC, USA: Pew Hispanic Center and the Multilateral Investment Fund; 2002.

45. Bank of Mexico. Ingresos por Remesas/Remittances Income. Available from: http://www.banxico. org.mx/SieInternet/consultarDirectorioInternetAction. do?accion $=$ consultarCuadro\&idCuadro $=$ CE81\&locale $=$ es (accessed on 10 August 2012).

46. International Fund for Agricultural Development. Sending money home: Worldwide remittance flows to developing countries. Available from: http:// www.ifad.org/remittances/maps (accessed on 8 January 2013).

47. Duany J. To send or not to send: Migrant remittances in Puerto Rico, the Dominican Republic, and Mexico. The ANNALS of the American Academy of Political and Social Science. 2010;630(1):205-223.

48. Orozco M. Migration and remittances in times of recession: Effects on Latin American and Caribbean economies. SP/Di No 5-09. Caracas, Venezuela: Latin American and Caribbean Economic System, Permanent Secretariat; 2009.

49. Loveday J, Molina O. Cuál es el impacto de las remesas internacionales en el bienestar? Economía y Sociedad. 2005;58:15-21.

50. Orozco M, Reifsteck J. Remittances and Policy Issues. Paper prepared for the Inter-American Dia- 
logue Conference: Policy Research on Remittances to Latin America and the Caribbean, Washington, DC, USA, 14 March 2007.

51. López Córdova JE. Globalization, migration, and development: The role of Mexican migrant remittances. Economía. 2005;6(1):217-256.

52. New London County CTGenWeb. New London County Connecticut Town Information. Available from: http://www.ctgenweb.org/county/conewlondon/towns /towns.html (accessed on 14 September 2013).

53. U.S. Census Bureau. New London City, Connecticut. Available from: http://quickfacts.census.gov/ qfd/states/09/0952280.html (accessed on 12 September 2013).

54. City of New London, Connecticut. Available from: www.ci.new-london.ct.us (accessed on 21 June 2011).

55. U.S. Census Bureau. Hispanic or Latino Origin by Specific Origin. Available from: http://factfinder2. census.gov/faces/tableservices/jsf/pages/productview. xhtml?pid=ACS_10_5YR_B03001\&prodType =table (accessed on 12 September 2013).

56. U.S. Census Bureau. Poverty Status in the Last 12 Months. Available from: http://factfinder2.census. gov/faces/tableservices/jsf/pages/productview.xhtml? pid=ACS_11_1YR_S1701\&prodType=table (accessed on 12 September 2013).

57. Nationally, the median age of Hispanics is 27. Since our participants had resided in the U.S. for approximately 11 years, it became apparent that participants had migrated to the U.S. in their late 20 s or early 30 s.

58. U.S. Census Bureau. Poverty Thresholds for 2012 by Size of Family. Available from: http://www. census.gov/hhes/www/poverty/data/threshld/index.ht $\mathrm{ml}$ (accessed on 15 July 2013).

59. Survey of Hispanic Familism and Remittances, 2009-2012, our survey.

60. Pearson WS, Ahluwalia IB, Ford ES, Mokdad AH. Language preference as a predictor of access to and use of healthcare services among Hispanics in the United States. Ethnicity and Disease. 2008;18(1):9397.

61. DuBard CA, Gizlice Z. Language spoken and differences in health status, access to care, and receipt of preventative services among US Hispanics. American Journal of Public Health. 2008;98(11):2021-2028. 